\title{
Late Pleistocene estuaries, palaeoecology and humans on North America's Pacific Coast
}

\author{
Jon Erlandson ${ }^{1}$, Torben Rick ${ }^{2}$, Amira Ainis ${ }^{1}$, Todd Braje ${ }^{3,{ }^{*} \text {, }}$ \\ Kristina Gill ${ }^{1} \&$ Leslie Reeder-Myers ${ }^{4}$
}

Human use of estuarine shellfish and other coastal marsh resources began on California's Santa Rosa Island at least 11800-11100 years ago. Productive estuaries in California and elsewhere in the Americas were present by the Late Pleistocene, providing shellfish, waterfowl, fish and seaweeds that attracted some of the First Americans.

Keywords: California, Santa Rosa Island, Channel Islands, Late Pleistocene, Holocene, palaeoecology, coastal resources, First Americans

Estuaries and coastal marshes are among the most productive, diverse and threatened ecosystems on earth. Archaeologists often assume that the productivity of estuaries, and their attractiveness to humans, increased significantly during the Mid-Holocene as sea-level rise slowed (Day et al. 2012: 26), fostering a florescence of coastal settlement and estuarine resource use. In some areas (e.g. San Francisco Bay) this is true, but rapid post-glacial sea-level rise created numerous earlier estuaries by flooding the mouths of coastal drainages (Graham et al. 2003). For coastlines adjacent to broad continental shelves, such estuaries would have been located far from modern shorelines, and archaeological evidence for their use is probably submerged far offshore. On relatively steep and narrow continental shelves such as those of the Pacific Coast of the Americas, however, early post-glacial estuaries would have been located much closer to the modern coast, and archaeological evidence for their existence is more likely to be discovered.

The Pleistocene-Holocene transition was a time of major ecological change, when global climatic regimes shifted from glacial to interglacial conditions and rapidly rising seas flooded continental shelves, with major ramifications for global geography and biodiversity. Humans first colonised the Americas at this time, probably between 20 000-15000 years ago. For most of the twentieth century, archaeologists focused on the interior 'ice-free corridor' as the entry route for the First Americans, with these Palaeoindians viewed as big-game hunters who preyed primarily on mammoths, mastodons, bison and other large mammals.

1 Museum of Natural \& Cultural History, University of Oregon, 1680 East 15 $5^{\text {th }}$ Avenue, Eugene, OR 97403, USA

2 Department of Anthropology, National Museum of Natural History, Smithsonian Institution, $10^{\text {th }}$ Street and Constitution Avenue NW, Washington, D.C. 20560, USA

3 Department of Anthropology, San Diego State University, 5500 Campanile Drive, San Diego, CA 92182, USA

4 Department of Anthropology, Temple University, 1801 North Broad Street, Philadelphia, PA 19122, USA

* Author for correspondence (Email: tbraje@sdsu.edu)

(C) Antiquity Publications Ltd, 2019

ANTIQUITY 93 372, e32 (2019): 1-5

https://doi.org/10.15184/aqy.2019.185 
For decades, evidence for human occupation of New World coastal zones lagged behind interior regions, with little evidence for human use of coastal resources earlier than 9000$10000 \mathrm{cal} \mathrm{BP}$. Archaeological and genomic discoveries have closed this gap, shifting the focus to the Pacific Coast as the most probable dispersal route for the First Americans (Braje et al. 2017). The 'kelp highway' hypothesis proposes that the ecological similarity and biodiversity of Pacific Rim kelp forests may have facilitated the dispersal of maritime peoples from North-east Asia to the Americas (Erlandson et al. 2007). Pacific Coast estuaries also contained productive and species-rich habitats, however, including anadromous fish runs that may have led people deep into continental interiors.

As more and earlier coastal sites have been identified in the Americas, interest has grown in how Palaeoindians interacted with and affected coastal ecosystems. On California's Santa Rosa Island, we have identified evidence for human use of estuarine shellfish and coastal marsh resources 11 800-11 100 years ago, extending the use of such ecosystems in Alta California by nearly two millennia.

Santa Rosa Island is one of four northern Channel Islands, formerly united as one large island (Santarosae) before rising seas separated them 11 000-9000 years ago (Figure 1). Separated from the mainland by a $6-8 \mathrm{~km}$-wide strait, Santarosae was $125 \mathrm{~km}$ long, with a land area roughly four times the size of the modern northern Channel Islands. Until 9000 years ago, the 8km-wide Santa Cruz Channel that now separates Santa Rosa and Santa Cruz islands was broad lowland, with a land bridge to the north and a south-facing embayment (Crescent Bay) to the south. At the centre of Crescent Bay was a deep submarine canyon, into which flowed several of Santarosae's largest drainages. Today, there are no estuaries on the northern Channel Islands, but archaeological and palaeoecological data show that an estuary existed on south-eastern Santa Rosa Island between 8500 and 5000 years ago (Rick et al. 2005). Pollen cores in the area document a transition from estuarine to freshwater marsh habitats over the past 7000-6000 years (Anderson et al. 2009).

In 2011, we recorded a shell midden (CA-SRI-708) on eastern Santa Rosa Island that contains Palaeocoastal components dated between 11300 and 9000 years ago. Excavation of Palaeocoastal midden deposits produced large quantities of rocky intertidal California mussels (Mytilus californianus), smaller amounts of estuarine shellfish and more than 600 birdbone fragments from waterfowl (geese/ducks). From this Palaeocoastal component, three shells of the estuarine Venus clam (Chione undatella) produced AMS radiocarbon dates of $10255 \pm 40 \mathrm{BP}, 10400 \pm 45 \mathrm{BP}$ and $10410 \pm 35 \mathrm{BP}$, harvested between $11300-10850 \mathrm{cal}$ BP (Figure 2).

Associated with these faunal remains were Channel Island Barbed points consistent with this period and chipped-stone crescents used as transverse projectile points for hunting birds. CA-SRI-512, a midden on Santa Rosa Island's north coast, produced similar Palaeocoastal artefacts, hundreds of waterfowl bones and six AMS radiocarbon dates (three on goose bones, three on charcoal) ranging from $12000-11350 \mathrm{cal}$ BP (Erlandson et al. 2011).

For Santa Rosa, archaeological data now indicate a sustained human harvest of kelp forest, rocky shore, and estuarine and marsh resources between at least 12000 and 10850 years ago, including intensive shellfishing, marine fishing and the hunting of migratory waterfowl and marine mammals. These aquatic resources complemented a wealth of carbohydrate-rich terrestrial plant foods on the island, especially edible geophytes (Gill 2016).

(C) Antiquity Publications Ltd, 2019 


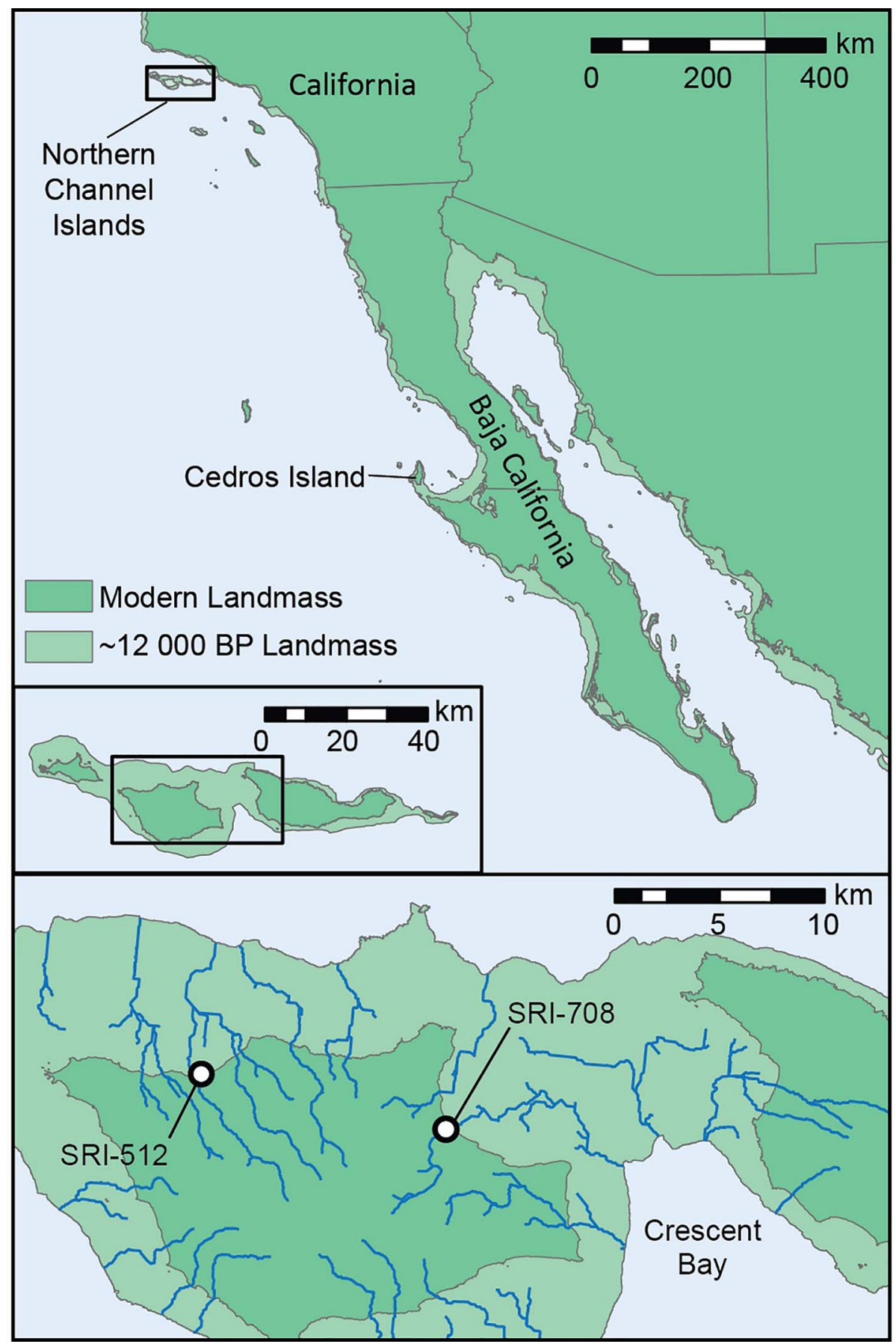

Figure 1. The location and palaeogeography of California's northern Channel Islands (palaeoshoreline estimate does not account for post-transgressive sediments deposited offshore). 


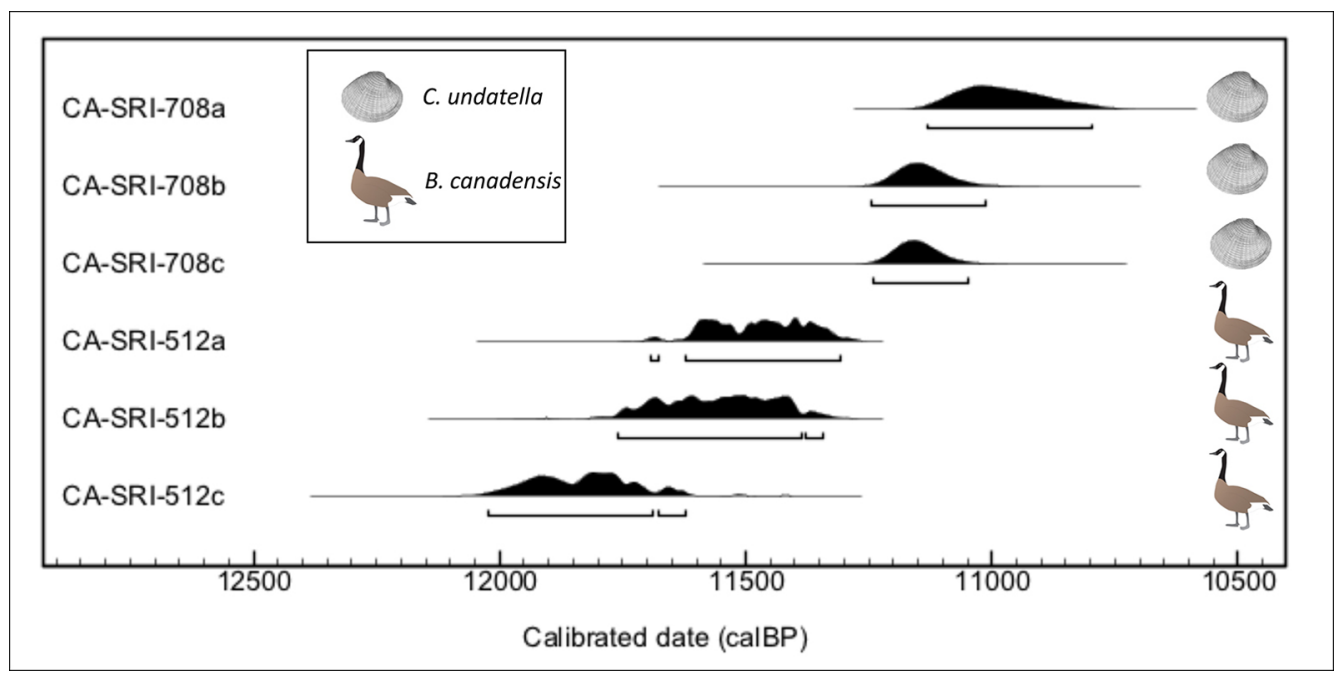

Figure 2. Calibrated radiocarbon age ranges for estuarine and coastal marsh resources from Santarosae archaeological sites (calibrated using OxCal 4.3 and the Marine 13 curve for shell samples $(\Delta R 261 \pm 21)$ and the IntCal13 curve for bird bones, Bronk Ramsey (2009); Reimer et al. (2013)).

On Baja California's Cedros Island, Des Lauriers (2010) also documented a maritime culture dating back nearly 12000 years, including faunal assemblages with small amounts of estuarine clams (Chione spp.). People harvested fish and other resources from estuarine habitats at Huaca Prieta in Peru as early as 15000 years ago (Dillehay et al. 2017), and estuarine and marine seaweeds at Monte Verde II in Chile 14000 years ago (Dillehay et al. 2008). McLaren et al. (2018) also documented 13 000-year-old human footprints in estuarine muds on a British Columbia beach.

Collectively, Pacific Coast archaeological data demonstrate that productive estuaries and marshes played a significant role in the peopling of the Americas. Tracking the evolution of these landscapes can help identify early coastal archaeological sites and evaluate the viability and timing of migrations into the New World. As research continues above and below the sea, further evidence for early estuarine resource use will probably emerge, especially in areas where narrow continental shelves are most likely to preserve evidence for early coastal foraging.

\section{Acknowledgements}

Our research was supported by the National Science Foundation (\#BCS 0917677), Edna English Trust for Archaeological Research, UO Museum of Natural \& Cultural History's Paleoindian Endowment and our home institutions. We thank Chumash consultants Mark Garcia, Paula Pugh and Alan Salazar for field support, and Ann Huston and Laura Kirn for logistical support.

\section{References}

Anderson, R.S., S. Starratt, R.M. Brunner Jass $\&$ N. Pinter. 2009. Fire and vegetation history on Santa Rosa Island, Channel Islands, and long-term environmental change in southern

(C) Antiquity Publications Ltd, 2019
California. Journal of Quaternary Science 25: 78297. https://doi.org/10.1002/jqs.1358

Braje, T.J., T.D. Dillehay, J.M. Erlandson, R.G. KLEIN \& T.C. Rick. 2017. Finding the first Americans. Science 358: 8-10. https://doi.org/10.1126/science.aao5473 
Bronk Ramsey, C. 2009. Bayesian analysis of radiocarbon dates. Radiocarbon 51: 337-60. https://doi.org/10.1017/S0033822200033865

DaY JR, J.W., J.D. GunN, W.J. Folan, A. Yáñez-Arancibia \& B.P. Horton. 2012. The influence of enhanced post-glacial coastal margin productivity on the emergence of complex societies. Journal of Island and Coastal Archaeology $7: 23-52$. https://doi.org/10.1080/15564894.2011.650346

Des Lauriers, M.R. 2010. Island of fogs: archaeological and ethnohistorical investigations of Isla Cedros, Baja California. Salt Lake City: University of Utah Press.

Dillehay, T.D., C. Ramírez, M. Pino, M.B. Collins, J. Rossen, J.D. \& Pino-Navarro. 2008. Monte Verde: seaweed, food, medicine, and the peopling of South America. Science 320: 784-86. https://doi.org/10.1126/science.1156533

DilleHAY, T.D. et al. 2017. Simple technologies and diverse food strategies of the Late Pleistocene and Early Holocene at Huaca Prieta, coastal Peru. Science Advances 3(5): e1602778. https://doi.org/10.1126/sciadv.1602778

Erlandson, J.M., M.H. Graham, B.J. Bourque, D. Corbett, J.A. Estes \& R.S. Steneck. 2007. The kelp highway hypothesis: marine ecology, the coastal migration theory, and the peopling of the Americas. Journal of Island and Coastal Archaeology 2: 161-74.
ErLandson, J.M. et al. 2011. Paleoindian seafaring, maritime technologies, and coastal foraging on California's Channel Islands. Science 331: 1181-85. https://doi.org/10.1126/science.1201477

GILL, K.M. 2016. 10000 years of geophyte use among the Island Chumash of the northern Channel Islands. Fremontia 44: 34-38. https://doi.org/10.1080/15564890701628612

Graham, M.H., P.K. Dayton \& J.M. Erlandson. 2003. Ice ages and ecological transitions on temperate coasts. Trends in Ecology and Evolution 18: $33-40$. https://doi.org/10.1016/S0169-5347(02)00006-X

Mclaren, D., D. Fedje, A. Dyck, Q. Mackie, A. Gauvreau \& J. Cohen. 2018. Terminal Pleistocene epoch human footprints from the Pacific Coast of Canada. PLoS ONE 13: e0193522. https://doi.org/10.1371/journal.pone.0193522

ReIMER, P.J. et al. 2013. IntCal13 and Marine13 radiocarbon age calibration curves $0-50000$ years cal BP. Radiocarbon 55: 1869-87. https://doi.org/10.2458/azu_js_rc.55.16947

Rick, T.C., D.J. Kennett \& J.M. ErLandson. 2005. Archaeology and paleoecology of the Abalone Rocks Estuary, Santa Rosa Island, California, in D. Garcelon \& C. Schwemm (ed.) Proceedings of the Sixth California Islands Symposium: 237-45. Arcata (CA): Institute for Wildlife Studies \& National Park Service.

Received: 14 May 2019; Revised: 25 June 2019; Accepted: 3 July 2019 